\title{
Józef Struś (Josephus Struthius) translator of Galen. The case of De antidotis
}

Józef Struś (Josephus Struthius), traducteur de Galien. Le cas du De antidotis

\section{Simone Mucci}

\section{(2) OpenEdition \\ Journals}

Electronic version

URL: https://journals.openedition.org/aes/3889

DOI: $10.4000 / a e s .3889$

ISSN: 2258-093X

\section{Publisher}

Laboratoire LISAA

\section{Electronic reference}

Simone Mucci, "Józef Struś (Josephus Struthius) translator of Galen. The case of De antidotis", Arts et Savoirs [Online], 15 | 2021, Online since 25 June 2021, connection on 17 December 2021. URL: http:// journals.openedition.org/aes/3889; DOI: https://doi.org/10.4000/aes.3889

This text was automatically generated on 17 December 2021 .

Centre de recherche LISAA (Littératures SAvoirs et Arts) 


\title{
Józef Struś (Josephus Struthius) translator of Galen. The case of De antidotis
}

\author{
Józef Struś (Josephus Struthius), traducteur de Galien. Le cas du De antidotis
}

\author{
Simone Mucci
}

I would like to thank Caroline Petit, James Nicholas Currie, and the anonymous reviewers for their valuable comments on this article.

1 This article offers a textual analysis of the translation of the Galenic work Mepi $\dot{\alpha} v \tau \imath \delta o ́ \tau \omega v$ (De antidotis, On antidotes; two books ${ }^{1}$ ) made by the Polish physician and humanist Josephus Struthius (latinised name of Józef Struś), with a particular focus on philological matters. Focusing primarily on book I, I intend to assess the quality of his translation, which he declared to be superior to that of Guinterius Andernacus, and to investigate the Greek sources employed by Struthius. I aim to demonstrate that Struthius did not resort to any ancient manuscripts for his translation, and that his criticism towards Andernacus, which is comparable with Galen's aggressive attitude towards his rivals, is largely unjustified.

Except a fragmentary but important papyrus of the sixth century $\mathrm{AD}^{2}$, the oldest witness of De antidotis is Firenze, Biblioteca Medicea Laurenziana, Plut. 74,5 (L) dated to early the twelfth century and attributed to the hand of $B$, the anonymous scribe and colleague of Ioannikios. This manuscript provides a lacunous text of book I, although it does preserve readings and recipes that are not attested elsewhere ${ }^{3} . \mathrm{L}$ is the antigraph ${ }^{4}$ of Paris, Bibliothèque Nationale de France, Supplément gr. 35 (N), which was used by the Aldine printers ${ }^{5}$. Venezia, Biblioteca Nazionale Marciana, gr. Z. 281 (M) was copied by Georgios Alexandrou ${ }^{6}$ in the second half of the XV century (probably between 1468 and $1472^{7}$ ) and contains several Galenic works. It is not one of the apographs of $\mathrm{L}$ as far as book I of De antidotis is concerned; the papyrus and M preserve the text of chapters 8 and 9 of book $\mathrm{I}^{8}$, which is omitted in $\mathrm{L}^{9}$. $\mathrm{M}$ was thus copied from a lost antigraph containing the whole text of book I of De antidotis without the omissions of $\mathrm{L}^{10}$. Paris, 
Bibliothèque Nationale de France, gr. $2164(\mathrm{P})$ was well known to the Aldine printers and preserves several handwritten marginal notes containing corrections and conjectures $^{11}$. P's role in the printed transmission of De antidotis is still not clear, but it is almost certainly a copy of M. The antigraph of Copenhagen, Det Kongelige Bibliotek, GKS $2252^{\circ}(\mathrm{H})$, copied in the late fifteenth or early sixteenth century by Petros Hypselas $^{12}$, is unknown too: it could be the lost antigraph of $\mathrm{M}^{13}$. The Aldine edition contains many peculiar readings of $\mathrm{H}$, and $\mathrm{H}$ was probably used by the Aldine printer for the 1525 edition of De antidotis ${ }^{14}$. Vienna, Österreichische Nationalbibliothek, Med. gr. $48(\mathrm{~V})$ is dated to the second half of the thirteenth century and contains several extracts of medical authors, including part of chapter 5 of book I of De antidotis and the poetical recipe of the Theriac of Andromachus the Elder ${ }^{15}$. It was not copied from $\mathrm{L}$ and its antigraph is unknown. My provisional conclusion is that $\mathrm{L}, \mathrm{M}$, and $\mathrm{H}$ (and also the papyrus and $\mathrm{V}$ for the small portion of text they preserve) are the fundamental witnesses to the text of book I of De antidotis, and that $\mathrm{H}, \mathrm{P}$, and $\mathrm{N}$ played a role in the printed transmission of the work ${ }^{16}$. The editio princeps of De antidotis was the 1525 Aldine edition (Venice), but it also appeared in Cratander's edition of Galen's works in 1538 (Basel) and in the collected works of Hippocrates and Galen edited by René Chartier (Paris, 1639). The text of Chartier (including the Latin translation) is reproduced with minor variations in the fourteenth volume of Karl Gottlob Kühn's Galeni opera omnia (Leipzig, 1827), which remains the standard edition of De antidotis since a critical edition of the work has never been produced ${ }^{17}$. Let us now turn to the life and works of Josephus Struthius.

3 Józef Struś ${ }^{18}$ was born in Poznań in 1510 to a bourgeois family of merchants. He attended the Lubrański Academy and studied Latin under the guidance of his maternal uncle Thomasz Bederman, who was a lawyer and rector of the aforementioned academy ${ }^{19}$. He left Poznań and moved to Kraków where he obtained a bachelor's degree (1529) and a masters' degree (1531) in medicine. While in Cracow he authored some Latin poems, a commentary to Lucian's Astrologia, and a Latin translation of Lucian's $\Delta i ́ k \eta \varphi \omega v \eta \varepsilon ́ v \tau \omega v$ (Iudicium vocalium, The consonants at law) ${ }^{20}$. According to Włodzimier Bugiel, other literary works of Struthius composed in that period may now be lost ${ }^{21}$. In 1532, Struthius moved to Padua, where he was a colleague of Andreas Vesalius. In those years authors like Hippocrates, Galen, and Avicenna were studied at the university ${ }^{22}$ and learned scholars like Lazzaro Bonamico read and taught classics there ${ }^{23}$. Padua was a stimulating centre for the study of medicine and ancient Greek and Latin literature: the Latin translations of Struthius date from his Paduan years. In 1535, he was appointed extraordinary professor of theoretical medicine. He remained in Padua until 1537, when he moved back to Poznan to take up the position of personal physician of the general Andrzej Górka (1538). Struthius also served as the personal physician of Isabella, wife of the king of Hungary John Zàpolya (1539), and of the Sultan Suleiman I the Magnificent (who asked him in vain to remain at his court); he also declined an invitation to become the personal physician of Philip II, king of Spain. In 1559, Struthius was appointed court physician by the Polish king Sigismund II Augustus. He spent his last years in his hometown, of which he was burgomaster in 1557 and 1558, and he died from plague, along with 6000 fellow citizens, in 1568 or 1569. His pioneering major work on the pulse, called Ars sphygmica, was printed in Basel in 1540 and reprinted in 1555, 1573 and $1602^{24}$. According to Bugiel ${ }^{25}$, in the period between 1535 and 1540, Struthius made the following Latin translations of Galenic works:

- De urinis (pseudo-Galenic ; Venice, 1535). 
- Astrologia ad Aphrodisium sive Prognostica de decubitu infirmorum ex mathematica scientia (pseudo-Galenic ; Venice, 1535).

- De paratu facilibus (allegedly appeared in Josephus Tectander's Galeni Pergameni opera, Basel, 1536)

- De antidotis (Venice, 1537).

- Commentariorum libri III in librum Hippocratis de fracturis (Venice, 1538).

- Commentariuorum libri IV in librum Hippocratis de articulis (Venice, 1540).

There are several errors in this list. In addition to Richard Durling's Census ${ }^{26}$, I have consulted the digital reproduction of the volume printed in Venice in 1536 by Giovanni Antonio Nicolini da Sabbio ${ }^{27}$, a copy of which is now in the Wellcome Library of London, which contains the translations of De antidotis (called Antidotarius liber), Astrologia, and De urinis in order to check their dates. In this copy, the translation of De antidotis is dated 1536 (e.g. f. 1r) ${ }^{28}$ and not 1537. I have also been unable to locate any copy of the 1537 edition of Struthius' translation of De antidotis that was printed in Venice ${ }^{29}$. Astrologia bears the date 11 January 1535 and was printed in Padua, not in Venice (f. $113 \mathrm{v}$ ), and De urinis is dated to 3 January 1525 and was printed in Padua too (f. 136v). The date 1525 is certainly a printer's mistake: Struthius could not be in Padua at the age of 15, but there are no reasons to question the correct date being 1535 .

Moreover, the translation of De paratu facilibus, which appears in Tectander's Cl. Galeni Pergameni medicorum post Hippocratem principis, opera omnium utilissima (published in Basel in 1536 by Andreas Cratander), was not made by Struthius: its author is in fact Hubertus Barlandus Philiatrius, who also translated De crisibus ${ }^{30}$. As far as the translations of the Galenic commentaries on Hippocrates' De fracturis and De articulis are concerned, I have found no trace of them. Thus, I have only been able to establish that Struthius translated the following Galenic or pseudo-Galenic works: De urinis, Astrologia ad Aphrodisium, and De antidotis. The two translations of De urinis and Astrologia, which had been already printed in 1535, also appeared in Tectanders' Galeni opera (1536) and were reprinted several times in the subsequent years ${ }^{31}$. On the other hand, Struthius' translation of the Antidotarius liber was never printed again.

One of the most interesting features of the translation of De antidotis is the substantial series of notes added to the text of the work. Whereas in book I there are only marginal notes, in book II several paragraphs in smaller characters are incorporated in the main text: they often interpret, correct, or update the work of Galen. For instance, just after the prologue of book II (ff. 47v-48r), Struthius added a detailed description of weights and measures; in particular at f. 48r there is a table that defines the units of measurement used for liquids such as oil, wine, and honey. It is possible that such a table had a practical purpose, namely that of being used by students or physicians. Although this purpose in not clearly stated anywhere in the volume, a marginal note at f. $16 \mathrm{v}$ seems to allude to the actual use of De antidotis by physicians: "Nos carmina Andromachi soluta oratione exposuimus; sciebamus enim nos eo pacto magis gratificaturos nostris medicis" ("We presented the poems of Andromacus in prose, for we knew that in this way we would gratify more our physicians"). Another interesting example taken from book II is the note at ff. $48 \mathrm{v}-49 \mathrm{v}$. In this long paragraph, Struthius discusses linguistic issues (for instance, the various names of plants) and provides readers with information about the provenance of some ingredients. In this respect Struthius adopts an approach similar to that of Galen himself, who talks extensively about the origin of the ingredients of the Theriac in book I and also discusses various 
linguistic problems related to their names. In the notes of book II, Struthius mentions various places that could not have appeared in De antidotis, such as Poland (e.g. f. 50r and f. 54v; in this second occurrence he proudly compares Polish honey to Attic honey, which is frequently mentioned and praised by Galen), Portugal (f. 54v), Austria, and Moravia (f. 60v). Arabic words and the philosopher Avicenna are mentioned in a note at f. 56v. In other notes, Struthius refers to various Galenic works (5r: "De hoc lege libro [sic!] ii" "Read book II about this"), and he helps readers to disambiguate the Galenic

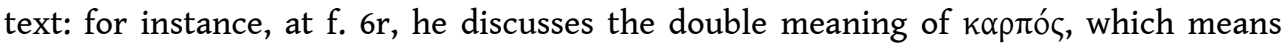
both fructus "fruit" and semen "seed," and at f. 39v he specifies the difference bewteen mortarium and pila ("mortar"). Overall, the notes give that impression of an updated, enlarged version of De antidotis; what it is less clear is whether it could be still employed in a functional way in the sixteenth century. Finally, in several cases, Struthius refers to "nostri" "our people" (e.g. ff. 24v, 25v, 26v, 32r, 33r) but their identity is not clearly mentioned. It is possible that he was referring to the Polish people.

Several notes refer to the Latin translation of De antidotis made by Joannes Guinterius Andernacus, and printed in Paris in 1533. Johann Winter von Andernach was born in poverty in 1487,1497 , or $1505^{32}$, and he lived and studied in various places across Europe (including Utrecht, Louvain, Paris, Metz, and Strasbourg). He was professor of Greek and medicine (he also taught Vesalius), and he was a prolific author and translator. He was a particular expert of ancient Greek medical texts, and he translated Hippocrates, Paul of Aegina, Alexander of Tralles, and Galen into Latin. Many of the notes from Struthius' translation, however, talk about him in unflattering terms. For instance, Struthius states that he was sleeping while translating a passage of the work ("dormivit" "he was sleeping", f. 6v), and Guinterius is often labelled with adjectives like "difficilis" ("difficult", 7v), "falsus" ("false", 12r) and "negligens" ("sloppy", 6v). Struthius declares in the second preface to the volume: "Nollem librum hunc Galeni ita parvi usus apud studiosos fore ut sunt libri illi septem de compositione

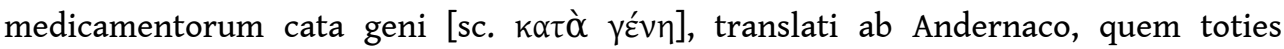
execratur lectores quoties ipsos legunt" ("I do not wish this Galenic book to be of such little use for scholars, as those seven books of Galen on the composition of remedies according to kinds translated by Andernach, who is cursed by readers every time they consult them"). He then intensifies his judgment on his predecessor: "In comparandis Graecis vetustissimis et optimis codicibus magnos sumputs facere aut nolit aut non possit" (“[He] either can't or won't go to the great expense of acquiring really good Ancient Greek manuscripts"). Struthius frequently wrote that Guinterius lacked a proper Greek model for his translations and rarely praises him (see 6r and 13r). Guinterius was aware of his own haste as translator ${ }^{33}$, but Struthius' claims on his sloppiness and ineptitude need to be assessed.

What Greek sources of De antidotis were available to Guinterius and Struthius when they made their translations? The Aldine edition, printed in 1525, was surely available to them. As the Cratander edition was published in Basel in 1538, Guinterius and Struthius could only have had the Aldine printed edition at their disposal. Let us focus now on a couple of passages that led Struthius to question the validity of Guinterius' Greek model. The first example is XIV 15,15:

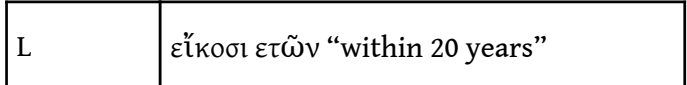




\begin{tabular}{|c|c|}
\hline M & 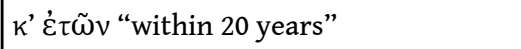 \\
\hline $\mathrm{H}$ & $\pi \rho o ̀ ~$ k’ $^{\varepsilon} \tau \tilde{\omega} v$ “before 20 years” \\
\hline Aldine & $\pi \rho o ̀ ~ k ’ ~ \varepsilon ́ \tau \tilde{\omega} \nu$ “before 20 years” \\
\hline Guinterius & ante viginti prope annos "before 20 years" \\
\hline Struthius & decimo anno "within 10 years" \\
\hline
\end{tabular}

9 Accoridng to Struthius' marginal note, "Hic caruit bono exemplari Andernacus" ("Here Andernach lacked a good model"). Two important manuscripts, L and M, do not transmit the reading $\pi \rho$ ó "before", which is witnessed by $\mathrm{H}$ and was chosen by the Aldine editors. Both the variants are grammatically acceptable in Greek. Guinterius read almost the same text as $\mathrm{H}$ and the Aldine, whereas Struthius, just as $\mathrm{L}$ and $\mathrm{M}$, did not apparently read $\pi \rho$ ó. Most importantly he translated "ten" instead of "twenty"; the origin of this reading is not clear. Did he actually consult a good model, which is now lost or at least unknown, containing the variant? There is no evidence to support this

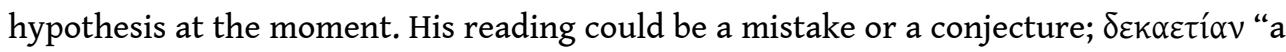
period of ten years" is mentioned in XIV 15,6, just a few lines above, and Struthius might simply have got confused.

The second example is XIV 20,2 seqq. All the manuscript witnesses (L, M, H, P, N) present the same text with just a few minor variations, whereas the two Latin translations are quite different:

\begin{tabular}{|c|c|c|}
\hline Aldine & Guinterius & Struthius \\
\hline 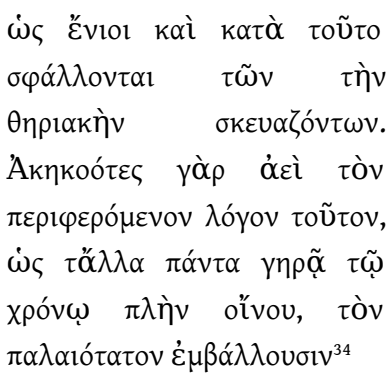 & $\begin{array}{l}\text { sicut nonnulli qui theriacen } \\
\text { praeparant in hoc quoque falluntur. } \\
\text { Quum enim audivissent semper } \\
\text { sermonem hunc celebrari } \\
\text { circumferrique, puta alia omnia } \\
\text { praeter vinum tempore } \\
\begin{array}{l}\text { consenescere, vetustissimum } \\
\text { iniiciunt }^{35}\end{array}\end{array}$ & $\begin{array}{l}\text { decipiuntur certe quam plurimi qui } \\
\text { theriacam conficiunt iniicientes } \\
\text { antidoto alia quidem vetera vinum } \\
\text { vero omnium vetustissimum, } \\
\text { credunt se eo pacto obtemperare } \\
\text { praceptis medicorum iubentium } \\
\text { vinum vetus antidotis imponi } i^{36}\end{array}$ \\
\hline
\end{tabular}

11 Again there is a marginal note: "Hic caruit certo, bono exemplari Andernacus" ("Here Andernach lacked a safe, good model"). It is not clear, however, that Guinterius lacked a good Greek model here: his translation looks literal, and while perhaps somewhat inelegant, it is accurate. On the other hand, Struthius substantially modifies the words of Galen: for instance "credunt se eo pacto obtemperare praceptis medicorum" is more a paraphrase, if not a rewriting, than a translation. The translation of Guinterius can help the reader understand the Greek text, whilst Struthius' translation stands on his own as a piece of Latin prose. Struthius' emphasis on literary quality could have led him to heavily and sarcastically criticise Guinterius:

In the sixteenth century, Latin was the universal language of what later became known as the Republic of Letters. The new humanist movement, first in Italy and 
then in Northern Europe, used Latin as both a cultural and a social marker. The Latin of the medieval clerics and schoolmen was pushed aside in favour of a return to the purer and more elegant Latin of Cicero and his Roman contemporaries. Educators throughout Western Europe proclaimed the superiority of their classical Latin to that of their medieval predecessors [...]. The way one wrote Latin thus took on a social role, differentiating a modern elite with shared educational values across the whole of Western Europe. ${ }^{37}$

12 As Durling put it, "[t] $]$ he sixteenth-century translators, as was only natural, tended to exaggerate their own achievements at the expense of their predecessors. Mistaking bad Latinity for ignorance, they were blind to the merits of the earlier translators, who had at least been faithful if inelegant." ${ }^{38}$ Within such a socio-cultural context there was a constant invidious comparison between the various scholars who dealt with Latin and Greek languages ${ }^{39}$ : "the ability to use and understand certain of the dead languages of Southern Europe is not only gratifying to the person who finds occasion to parade his accomplishments in this respect, but the evidence of such knowledge serves at the same time to recommend any savant to his audience, both lay and learned" 40 . According to Veblen, the absence of classical language knowledge "creates a presumption of hasty and precarious learning, as well as... a vulgar practicality" ${ }^{41}$. Struthius certainly felt no shame in displaying his mastery of Latin, and therefore his (supposedly) superior social and intellectual status by attacking the allegedly lower knowledge of Latin, or the quality of the Greek sources, of his colleague and competitor. Moreover, he might have felt the need to highlight the superiority of his new translation of De antidotis. Guinterius' translation was printed in 1533, only three years before Struthius', and was reprinted in 1536 in the edition of Tectander that also contained two Latin translations made by Struthius ${ }^{42}$. The two men were thus competitors in the medical book market.

13 Some of the most interesting notes of Struthius' translation deal with his own and Guinterius' models: while his predecessor is said to have resorted to a bad exemplar, Struthius claimed to have employed an "antiquissimus codex" of higher quality. In both cases, the translators do not make clear if their Greek models were medieval manuscripts or just printed editions. Let us consider a few more examples.

At XIV 22,11 Guinterius read Tibenum, whereas Struthius had Tubreum, which translates the manuscript transmission and the Aldine (Toúßprov). Struthius says that the antiquissimus codex bears this variant ${ }^{43}$, but this is impossible to verify because the reading is also in the Aldine edition. Interestingly, neither variant is attested elsewhere in Greek language; the Greek text may be corrupted.

15 At XIV 77,15-78,6 Struthius says that he added several words to his translation thanks to the very old manuscript he used and that Guinterius employed (as usual) a corrupted model. ${ }^{44}$ None of the extant manuscripts, however, present significant variants, damages, and mistakes in this passage. Moreover, Guinterius translated the whole passage quite literally and without mistakes or omissions.

16 At XIV 80,11, M, H, P, and the Aldine have the reading Mí $\lambda \tau \omega$, which is a mistake, whereas $\mathrm{L}$ and $\mathrm{N}$ have the correct variant $\Lambda \eta \dot{\mu} \mu \omega$. Guinterius reads Milto and Struthius Lemno: did Struthius actually resort to L or N? Both $\mathrm{L}$ and $\mathrm{N}$ contain huge lacunae and omit long passages of the work: although they preserve some good readings, they can hardly escape the definition of codices depravati that Struthius employed to describe Guinterius' Greek sources. More evidence is needed in order to establish that he resorted to L or $\mathrm{N}$. In this case, he might have easily corrected the text ope ingenii. 


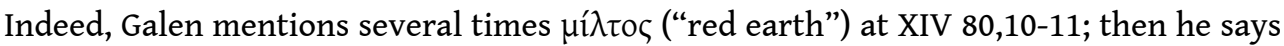

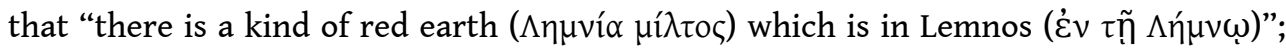
$\mathrm{M}, \mathrm{H}, \mathrm{P}$ and the Aldine have the wrong place name ( $\dot{\varepsilon} v \tau \tilde{n}$ Míl $\tau \omega)$, which is a simple mistake due to the presence of $\mu$ í $\lambda \tau$ тo $\zeta$ in the previous lines.

There are other passages on which Struthius did not comment in the notes, but again nothing seems to suggest that Struthius consulted an older, unknown manuscript.

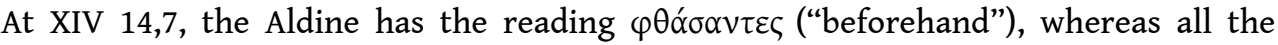

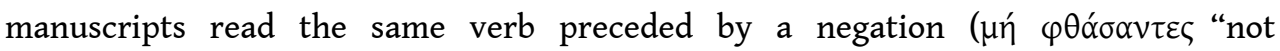
beforehand", which is probably the correct reading). Struthius translates "si primo quidem tempore acescere incipiant" ${ }^{25}$; the structure of the sentence is slightly changed but still there is no negation that translates $\mu$ r. Again, Struthius seems to have resorted to the printed edition rather than to an ancient manuscript.

19 At XIV 13,1, Kühn reads ö $\lambda \lambda \omega \varsigma$ ("otherwise") whereas all the manuscripts and the Aldine have the reading $\alpha$ ' $\lambda \lambda_{0 \varsigma}$ ("another"). It is not clear which is the correct one: both are grammatically correct and fit adequately the context. Struhius writes alteri cuidam ("to someone else"), which translates $\alpha$ $\lambda \lambda \lambda_{\text {oc, }}$, but this of course does not prove that he resorted to an ancient manuscript.

20 At XIV 26,17, Kühn has the correct reading трí $\beta \omega v \varepsilon \varsigma$ ("skilled people", already conjectured by Cornarius); all the manuscripts and the Aldine have the variant

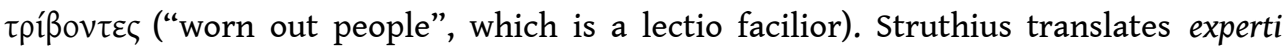
mercatores ("expert dealers"), which clearly resembles the reading of Kühn, but does not suggest that he resorted to any of the preserved manuscripts containing De antidotis. He might have corrected the wrong reading ope ingenii, as Cornarius also did.

We turn now to the style of the translation. Syncategorematic words, like adverbs, particles, pronouns, and conjunctions, are meaningful only in relation to other elements of the sentence. Translators tend to treat these words with relative consistency: they can therefore show the peculiar stylistic habits of a translator. In the mid twentieth century, Lorenzo Minio-Paluello developed a comparative linguisticstylistic method, which included the analysis of syncategorematic words, in order to investigate the authorship of the anonymous Latin translations of the Aristotelic Corpus. ${ }^{46}$ This same method was used more recently by Stefania Fortuna, Anna Maria Urso, and Christina Savino to assess various medieval and Humanistic Galenic translations ${ }^{47}$. This method can therefore be employed to show some of the stylistic differences between the two Latin translations of De antidotis. A detailed analysis of the translations of some syncategorematic words of the first three chapters of De Antidotis (about the $10 \%$ of the work) follows:

\begin{tabular}{|c|c|c|}
\hline Kühn & Guinterius & Struthius \\
\hline$\pi \alpha^{\prime} \lambda_{l v}$ & $\begin{array}{l}\text { Rursus (twice) } \\
\text { E contrario (once) } \\
\text { Not translated (once) }\end{array}$ & $\begin{array}{l}\text { Rursus (once) } \\
\text { E diverso (once) } \\
\text { Not translated (twice) }\end{array}$ \\
\hline 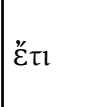 & $\begin{array}{l}\text { Amplius (once) } \\
\text { Adhuc (once) }\end{array}$ & $\begin{array}{l}\text { Nondum (once) } \\
\text { Not translated (once) }\end{array}$ \\
\hline
\end{tabular}




\begin{tabular}{|c|c|c|}
\hline 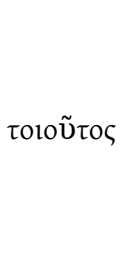 & $\begin{array}{l}\text { Eiusmodi ( } 3 \text { times) } \\
\text { Cuisumodi (once) } \\
\text { In eum modum (once) } \\
\text { Talis (twice) }\end{array}$ & $\begin{array}{l}\text { Eiusmodi (3 times) } \\
\text { Qualis (once) } \\
\text { Talis (once) } \\
\text { Ille (once) } \\
\text { Non translated (once) }\end{array}$ \\
\hline$\delta \eta ́$ & Nunc (once) & Autem (once) \\
\hline үoũv & $\begin{array}{l}\text { Enim (once) } \\
\text { Itaque (once) } \\
\text { Sane (once) } \\
\text { Nam (once) }\end{array}$ & Not translated (4 times) \\
\hline 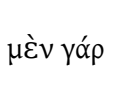 & $\begin{array}{l}\text { Siquidem (twice) } \\
\text { Sane (once) }\end{array}$ & $\begin{array}{l}\text { Enim (twice) } \\
\text { Not translated (once) }\end{array}$ \\
\hline 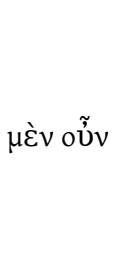 & $\begin{array}{l}\text { Igitur (4 times) } \\
\text { Iam (once) } \\
\text { Vero (once) } \\
\text { Itaque (once) }\end{array}$ & $\begin{array}{l}\text { Igitur (twice) } \\
\text { Quidem (once) } \\
\text { Enim (once) } \\
\text { Certe (once) } \\
\text { Not translated (twice) }\end{array}$ \\
\hline Ǒ $\tau$ l & Quia (once) & Quoniam (once) \\
\hline 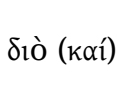 & $\begin{array}{l}\text { Hinc (once) } \\
\text { Quare (once) }\end{array}$ & $\begin{array}{l}\text { Vero (once) } \\
\text { Not translated (once) }\end{array}$ \\
\hline ஸँ $\sigma \varepsilon \varepsilon \rho$ & $\begin{array}{l}\text { Quemadmodum (8 times) } \\
\text { Sicut (twice) } \\
\text { Sicuti (once) } \\
\text { Uti (once) }\end{array}$ & $\begin{array}{l}\text { Sicut (once) } \\
\text { Veluti (once) } \\
\text { Quanto (once) } \\
\text { Not translated (9 times) }\end{array}$ \\
\hline 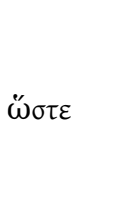 & $\begin{array}{l}\text { Quapropter (twice) } \\
\text { Quare (twice) } \\
\text { Ob quod (once) }\end{array}$ & $\begin{array}{l}\text { Quare (once) } \\
\text { Igitur (once) } \\
\text { Vero (once) } \\
\text { Not translated (twice) }\end{array}$ \\
\hline oǔ $\tau \omega(\varsigma)$ & $\begin{array}{l}\text { Ita (6 times) } \\
\text { Adeo (once) } \\
\text { Ita ut (once) } \\
\text { Not translated (once) }\end{array}$ & $\begin{array}{l}\text { Eam ob rem (once) } \\
\text { Tanto (once) } \\
\text { Ita (twice) } \\
\text { Eo modo (once) } \\
\text { Not translated (4 times) }\end{array}$ \\
\hline oîov & Veluti (once) & Not translated (once) \\
\hline
\end{tabular}




\begin{tabular}{|c|c|c|}
\hline ǒ $\tau \alpha \nu$ & $\begin{array}{l}\text { Quum (twice) } \\
\text { Quando (once) }\end{array}$ & $\begin{array}{l}\text { Et si (once) } \\
\text { Si (once) } \\
\text { Non translated (once) }\end{array}$ \\
\hline 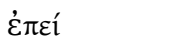 & Quum (once) & Not translated (once) \\
\hline$\gamma \varepsilon$ & $\begin{array}{l}\text { Verum (once) } \\
\text { Nam (once) } \\
\text { Certe (once) } \\
\text { Not translated (14 times) }\end{array}$ & $\begin{array}{l}\text { Vero (once) } \\
\text { Certe (once) } \\
\text { Nam (once) } \\
\text { Igitur (once) } \\
\text { Not translated (13 times) }\end{array}$ \\
\hline$\gamma \varepsilon \mu \eta ́ v$ & Tamen (once) & Tamen (once) \\
\hline 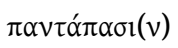 & Omnino (once) & Not translated (once) \\
\hline$\pi \alpha ́ v \tau \omega \varsigma$ & $\begin{array}{l}\text { Omnino (once) } \\
\text { Not translated (once) }\end{array}$ & Not translated (twice) \\
\hline
\end{tabular}

There are a number of stylistic differences between Guinterius and Struthius. For instance, in De antidotis, Galen frequently employed phrases and sentences beginning

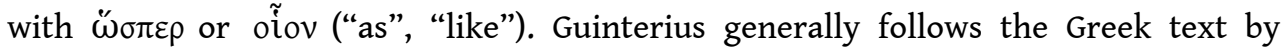
literally translating these kinds of expression (e.g. "quemadmodum" or "sicut"). Struthius, on the other hand, customarily avoids this construction and often simplifies the structure of the sentence. For instance, compare XIV 2,7-9 :

\begin{tabular}{|c|c|c|}
\hline Aldine & Guinterius & Struthius \\
\hline 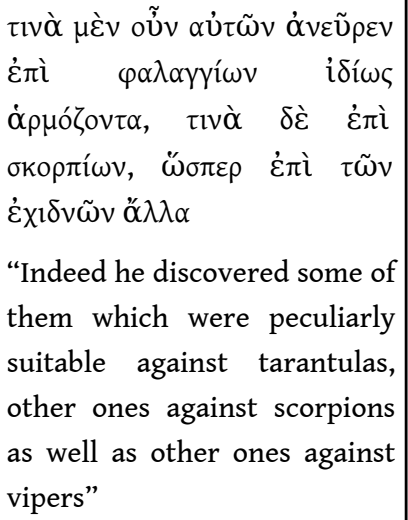 & $\begin{array}{l}\text { Quaedam igitur eorum comperit } \\
\text { adversus phalangia privatim } \\
\text { convenire, quaedam in scorpiones, } \\
\text { quemadmodum in viperas alia } \\
\text { "Indeed he discovered that } \\
\text { some of them are privately } \\
\text { suitable against tarantulas, } \\
\text { other ones against scorpions, } \\
\text { like other ones against vipers" }\end{array}$ & $\begin{array}{l}\text { Ex iis igitur alias reperit } \\
\text { phalangiorum veneno proprie } \\
\text { congruere, alias scorpionum, } \\
\text { viperarum alias } \\
\text { "Indeed he discovered that some } \\
\text { of them are particularly suitable } \\
\text { for the venom of tarantulas, } \\
\text { other ones for that of scorpions, } \\
\text { other ones for that of vipers" }\end{array}$ \\
\hline
\end{tabular}

Guinterius mistranslated i $\delta i ́ \omega \varsigma$ ("peculiarly") as privatim ("in private"); despite this mistake, his translation follows the Greek text literally (including the phrase beginning

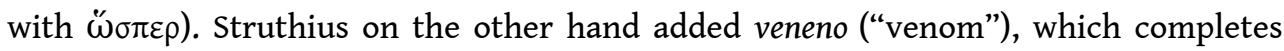
the meaning of the sentence but is not present in Galen's text; he also eliminated and simplified the structure of the sentence. 
Struthius also does not usually translate the adverbs containing the root $\pi \alpha v^{-}$"all". An example of this usage is XIV 3,11-13 :

\begin{tabular}{|c|c|c|}
\hline Aldine & Guinterius & Struthius \\
\hline 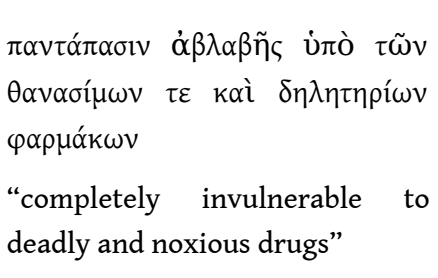 & $\begin{array}{l}\text { omnino a lethalibus et deleteriis } \\
\text { appellatis medicaminibus securus et } \\
\text { immunis } \\
\text { "completely safe from and } \\
\text { immune to lethal and noxious } \\
\text { medicines" }\end{array}$ & $\begin{array}{l}\text { ab omnibus venenis quae } \\
\text { deleteria vocantur securus et } \\
\text { immunis } \\
\text { "safe from and immune to } \\
\text { all poisons which are called } \\
\text { noxious }\end{array}$ \\
\hline
\end{tabular}

Guinterius translated the adjective $\dot{\alpha} \beta \lambda \alpha \beta \eta \dot{\zeta}$ as two adjectives, "securus et immunis"; the same hendiadys is employed by Struthius, who also transferred the semantic value of the adverb $\pi \alpha v \tau \alpha^{\prime} \pi \alpha \sigma i v$ ("completely") to the adjective "omnibus". Again, Struthius made more changes to the structure of the sentence than Guinterius. Furthermore,

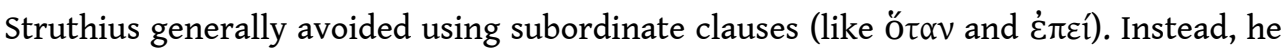
transformed them into coordinate clauses and thus simplified the structure of the sentence.

In conclusion, based on this preliminary study, Struthius' biting criticism of Guinterius' translation does not seem to be well founded. On the one hand, there is no evidence that Guinterius resorted to a faulty Greek model: he employed the Aldine edition for his translation of De antidotis, as he did for his other translations ${ }^{48}$. Struthius, as shown in the aforementioned examples, often has the same reading as the Aldine, which he probably employed too. The allegedly very old manuscript he claimed to have consulted (if it actually existed) left no trace in his Latin translation of De antidotis. On the other hand, the translation of Guinterius, which of course does contains a number of mistake, does not seem to be as incorrect as Struthius maintains. This translation, as already noted, is often literal and perhaps not very elegant, but it is generally faithful and helpful to understand literally the Greek text of work. Guinterius usually follows the word order of the Greek text in his Latin translation whereas Struthius frequently modifies or rebuilds entire sentences, adds comments, new sentences, or glosses and completes the work of Galen by adding new information to the work (sometimes in the marginal notes, sometimes in the main text). His translation is also a partial rewriting of De antidotis in Latin; it stands on its own as an autonomous Latin work and in this respect one can see the reason why he considered his own translation to be superior to that of Guinterius. In addition, perceiving other scholars and colleagues as rivals and attacking them was part of the socio-cultural climate of the time ${ }^{49}$. Within this historical context Struthius adopted an ego-driven approach of self-representation that resembles the approach of Galen himself. In the case of De antidotis, for instance, Galen criticised and sometimes mocked several people, ranging from famous old physicians like Quintus ${ }^{50}$ to street-sellers of drugs and anonymous practitioners of pharmacology ${ }^{51}$. The target of Struthius in De antidotis was of course Guinterius, his immediate predecessor and competitor, who he insulted in the marginal notes to his translation whenever he could. When Galen and Struthius present themselves in their own works as medical practitioners, their superior knowledge and skill often contrast with the wrong diagnoses and therapies of their competitors ${ }^{52}$. As practitioners and 
writers of pharmacology, both Galen and Struthius had at their disposal the best substances on the market - like Polish honey, which Struthius proudly compared to Attic honey - and they dealt with a range of linguistic, stylistic, and textual matters in what are ostensibly pharmacological works. Further research would enlighten the fascinating topic of Struthius' imitation of Galenic persona.

\section{NOTES}

1. Karl Gottlob Kühn, Claudii Galeni Pergameni opera omnia, vol. XIV, Leipzig, Knobloch, 1827, p. 1-209.

2. PLondLit 169 + PBodl MS gr. class. G 69 (see Raffaele Luiselli, "Galen, De Antidotis I 9 [addendum to PlondLit 169]", in Isabella Andorlini (ed.), Greek Medical Papyri I, Firenze, Istituto papirologico G. Vitelli, 2001, p. 37-49).

3. On $\mathrm{L}$ and the milieu of Ioannikios see the following fundamental works (containing further bibliography) : Vivian Nutton (ed.), Galeni de praecognitione, CMG V 8,1, Berlin, Akademie-Verlag Berlin, 1979, p. 17-18; Nigel Guy Wilson, "A mysterious Byzantine scriptorium : Ioannikios and his colleagues", Scrittura e civiltà $\mathrm{n}^{\circ} 7,1983$, p. 161-189; Jean-Marie Jacques, "Le manuscript de Florence Laurentianus gr. 74.5 et les écrits galéniques sur la theriaque et les antidotes", Revue des Études Anciennes n 101, 1999, p. 523-531 ; Vivian Nutton (ed.), Galeni De propriis placitis, CMG V 3,2, Berlin, Akademie-Verlag, 1999, p. 18 ; Véronique Boudon-Millot (ed.), Galien. Introduction générale ; Sur l'ordre de ses propres livres; Sur ses propres livres; Que l'excellent médecin est aussi philosophe, Paris, Les Belles Lettres, 2007, p. CLXXIV-CLXXXI ; Paola Degni, “I manoscritti dello 'scriptorium' di Gioannicio", Segno e testo, n 6, 2008, p. 179-248; Véronique Boudon-Millot (ed.), Galien. Thériaque à Pison, Paris, Les Belles Lettres, 2016, p. CLIII-CLVIII.

4. $\mathrm{N}$ is not the only apograph of L; another is Yale, Medical Library 37 (Y), which I not have yet consulted.

5. It is not clear whether $\mathrm{N}$ was used as the constitutio textus of the Aldine edition or just for its correction; see Philippe Hoffman, "Autres données relatives à un mystérieux collaborateur d'Alde Manuce, l'Anonymus Harvardianus ", in Mélanges de l'École française de Rome. Moyen-Âge, Temps modernes, t. 98, nº 2. 1986, p. 673-708, in particular 687-688; Stefania Fortuna, "Niccolò Leoniceno e le edizioni aldine dei medici greci (con un'appendice sulle sue tradizioni latine)", in Véronique Boudon-Millot, Amneris Roselli (eds.), Ecdotica e ricezione dei testi medici greci. Atti del V convegno internazionale (Napoli, 1-2 ottobre 2004), Napoli, D'Auria, 2006, p. 443-464, in particular p. 450.

6. Vivian Nutton, De propriis placitis, op. cit., , n² 2, p. 18. On Georgios Alexandrou see RGK I 54, RGK II 72, RGK III 89.

7. Vivian Nutton, De praecognitione, op. cit. p. 18.

8. The papyrus was discovered only in the nineteenth century: no humanist could have known it.

9. Raffaele Luiselli, op. cit., p. 42.

10. The textual history of book II may be quite different from that of book I: see Véronique Boudon-Millot, « Galien a-t-il lu Pline? À propos de la thériaque dite d'Antiochos (De antidotis II, 14 = Kühn XIV, 183, 7) », Revue des études grecques n 132, 2019/1, p. 117-127.

11. Véronique Boudon-Millot, Thériaque à Pison, op. cit., p. CLVIII-CLXIX.

12. RGK I 349 ; RGK II 478 ; RGK III 558. 
13. On $\mathrm{H}$ and its role in the transmission of Galen, see : Véronique Boudon-Millot, "La tradition manuscrite des Médicaments composés selon les genres de Galien (Kühn XIII, 362-1058): nouveaux apports", Revue des études grecques n 131, 2018/2, p. 451-478.

14. I have not yet consulted Vienna, Österreichische Nationalbibliothek, Suppl. gr. 13 (Vind), which is dated to the first half of sixteenth century. It is the apograph of $\mathrm{H}$ in the case of Theriac to Piso (Véronique Boudon-Millot, Thériaque à Pison, op. cit., p. CXLVIII and p. CLXIX).

15. Folios $164 \mathrm{v}-171 \mathrm{v}$. See Herbert Hunger, Otto Kresten, Katalog der griechischen Handschriften der Österreichischen Nationalbibliothek, Teil 2: Codices Juridici et Medici, Wien, G Prachner, 1969, p. 100-101.

16. There are other witnesses of Galen's De antidotis. For instance, Paris, Bibliothèque Nationale de France, gr. 2287 and Città del Vaticano, Biblioteca Apostolica Vaticana, Reg. gr. 173 only contain small excerpts of book II. I have not been able to consult Hagion Oros, Mone Iviron, 4339.219 and Hagion Oros, Mone Iviron, 4271.151.

17. For this reason the passages taken from De antidotis will be quoted according to the edition of Kühn: e.g. XIV 27,8= volume 14, page 27, line 8.

18. The following biographical data are mostly gathered from Włodzimier Bugiel, Un célèbre Médecin polonais au XVI e siècle, Joseph Struthius (1510-1568), Paris, Imprimerie de la faculté de médecine, 1901 (available at https://wellcomelibrary.org/item/b28034430\#? $\mathrm{c}=0 \& \mathrm{~m}=0 \& \mathrm{~s}=0 \& \mathrm{cv}=0 \& \mathrm{z}=-1.3846 \% 2 \mathrm{C}-0.0955 \% 2 \mathrm{C} 3.7693 \% 2 \mathrm{C} 1.9097$, last consulted on $01 / 09 / 2020$ ), Andrzej Grzybowski, Jarosław Sak, Jakub Pawlikowski, "500th anniversary of the birth of the precursor of modern cardiology: Josephus Struthius Polonus (1510-1568)", Cardiology Journal, $n^{\circ} 18,2011 / 5$, p. 581-586, online: https://journals.viamedica.pl/cardiology_journal/article/view/ 21213, and the record compiled by Richard Westfall, en ligne: http://galileo.rice.edu/Catalog/ NewFiles/struss.html (last consulted on 01/09/2020). There are some contradictions: for instance, Bugiel states that Struthius remained in Padua until 1545, whereas in the most recent literature he is said to have left Padua already in 1537. Moreover, Struthius himself provided his readers with some biographical details, which need to be carefully assessed. A critical study of the life of Struthius, which goes beyond the scope of this article, is therefore needed.

19. Włodzimier Bugiel, op. cit. p. 13; Richard Westfall, op. cit.

20. Lucian's Astrologia and Iudicium vocalium were printed tofgether in 1531 in Cracow (Luciani Samosatensis Astrologia Erasmo Rotterodamo interprete, Josephu Struthii Posnianensis In Luciani astrologiam commentariorum libri duo, Luciani Declamatio quaedam lepidissima Iosepho Struthio Posnaniense interprete). The two works are available at https://dbc.wroc.pl/dlibra/publication/ 2689/edition/2697/content (last consulted on 01/09/20).

21. Włodzimier Bugiel, op. cit. p. 20.

22. Andrzej Grzybowski, Jarosław Sak, Jakub Pawlikowski, op. cit. p. 583.

23. Rino Avesani, s.v. "Lazzaro Bonamico", in Dizionario biografico degli italiani, vol. XI, Roma, Istituto della Enciclopedia Italiana, 1969 (en ligne : http://www.treccani.it/enciclopedia/lazzarobonamico_\%28Dizionario-Biografico \%29/, last consulted on 01/09/20).

24. No copies of the 1540 edition are extant. For the significance of this work in the history of medicine, see: Włodzimier Bugiel, op. cit p. 50 ff. and Andrzej Grzybowski, Jarosław Sak, Jakub Pawlikowski, op. cit., p. 584-586.

25. Włodzimier Bugiel, op. cit., p. 46-48.

26. Richard Jasper Durling, "A Chronological Census of Renaissance editions and Translations of Galen", Journal of the Warburg and Courtauld Institutes $n^{\circ} 24,1961$, p. 230-305. The more recent Addenda to Census by Durling himself and Stefania Fortuna do not contain any new information about Struthius and his Latin translations (see Richard Jasper Durling, "Corrigenda and Addenda to Diels' Galenica: I. Codices Vaticani”, Traditio n²3, 1967, p. 461-476; Richard Jasper Durling, “Corrigenda and Addenda to Diels' Galenica: II. Codices miscellanei”, Traditio n 37, 1981, 
p. 373-381 ; Stefania Fortuna, Annamaria Raia, “Corrigenda and Addenda to Diels' Galenica by Richard J. Durling : III. Manuscripts and Editions”, Traditio n 61, 2006/1, p. 1-30).

27. Ibid., p. 259 ( $\mathrm{n}^{\circ}$ 1536.1).

28. As the reader may have already observed, the pagination of the volume is similar to that of medieval manuscripts. On f. 147v there is a list of "errores qui oculos chalcotyporum effugerant" ("errors which escaped detection of the typographers"): each listed folio has two pages, 1 and 2, corresponding to recto and verso. Thus Folio 6 pagina 2 corresponds to f. $6 \mathrm{v}$; in this article I will employ the modern system of pagination in order to avoid difficulties and confusion for readers.

29. This 1537 edition is nevertheless mentioned in some (often old) works, like Leonard Chodźko, Relazione storica, politica, geografica, legislativa, scientifica, letteraria, \&c. della Pollonia antica e moderna ultimamente pubblicata per le cure di Lionardo Chodzko, prima traduzione italiana, t. IV, Livorno, G. B. Pozzolini \& co., 1831, p. 182.

30. On this interesting figure see Richard Jasper Durling, op. cit., p. 238 and in particular $n^{\circ} 44$.

31. Richard Jasper Durling, op. cit. p. 292 ( $\left.\mathrm{n}^{\circ} 121\right)$ and 293 ( $\left.\mathrm{n}^{\circ} 140\right)$.

32. On Joannes Guinterius, see: least Vivian Nutton (ed.), Principles of Anatomy according to the Opinion of Galen by Johann Guinter and Andreas Vesalius, London-New York, Routledge, 2017, p. 22 and $n^{\circ}$ 86; Richard Jasper Durling, op. cit. p. 237, n 41; Caroline Petit (ed.), Galien. Le médecine. Introduction, Paris, Les Belles Lettres, 2009, p. CXVII-CXVIII (which contains an interesting discussion on the Latin translation of the Introductio sive medicus and a further bibliography).

33. "Guinter was forced to admit that the speed with which he translated gave him less time than he would have liked to check the readings of the Aldine edition against Greek manuscripts in local collections" (Vivian Nutton, Principles of anatomy, op. cit., p. 24).

34. "as some people, among those who prepare the theriac, also make this mistake. Indeed, because they use to hear from some people this saying - that all the other things except wine grow old with time - they cast in [the antidote] the oldest one".

35. "as some people who prepare the theriac also make this mistake. Indeed, after hearing continuously this narrative celebrated and widely circulated, you shall think that all the other things except wine lose force with time, they cast in [the antidote] the oldest one".

36. "So many people who prepare the theriac are deceived when they cast in the antidote other old ingredients and very old wine; they think that in this way they are observing the precepts of the physicians who order to use old wine in the antidotes."

37. Vivian Nutton (ed.), Principles of anatomy, op. cit. p. 23.

38. Richard Jasper Durling, op. cit. p. 238.

39. Thorstein Veblen, The theory of the leisure class, Oxford, Oxford University Press, 2009 (or. ed. New York, Macmillan, 1899), p. 21: "an invidious comparison is a process of valuation of persons in respect to worth".

40. Ibid, p. 256.

41. Ibid., p. 256.

42. De urinis and Astrologia: see Richard Jasper Durling, op. cit. p. 283.

43. Folio $11 \mathrm{v}$.

44. Folio $35 \mathrm{v}$.

45. "If they start becoming sour in the first period"; folio 7v.

46. Lorenzo Minio-Paluello, Opuscula. The Latin Aristotle, Amsterdam, Hakkert, 1972.

47. Stefania Fortuna, Anna Maria Urso, "Burgundio da Pisa traduttore di Galeno: nuovi contributi e prospettive", in Ivan Garofalo (ed.), Sulla tradizione indiretta dei testi medici greci. Atti del II seminario internazionale di Siena, Certosa di Pontignano, 19-20 settembre 2008, Pisa-Roma, Fabrizio Serra Editore, 2009, p.139-175; Christina Savino, "La traduzione di Lorenzo Lorenzi del Commento di Galeno agli Aforismo di Ippocrate : un caso di plagio ?", Medicina nei secoli - Arte e scienza $\mathrm{n}^{\circ}$ 25, 2013/3, p. 1023-1062.

48. E.g. Caroline Petit, op. cit. p. CXVIII. 
49. Vivian Nutton, Principles of anatomy, op. cit. p. 23; Richard Jasper Durling, op. cit. p. 238.

50. XIV 69,7 and XIV 70,13.

51. E.g. XIV 53,8; XIV 64,2. On the rhetorical and literary aspects of Galen's work see Simon Swain, Hellenism and Empire, Language, Classicism and Power in the Greek world 50-250 AD, Oxford, Oxford University Press, 1996 (in particular p. 357-379); Caroline Petit, Galien de Pergame ou la rhétorique de la Providence. Médecine, littérature et pouvoir à Rome, Leiden-Boston, Brill, 2018.

52. E.g. De praecognitione XIV 605-619 = 74,12-88,13 Nutton ; Ars sphygmica (ed. 1602), p. 84-86.

\section{ABSTRACTS}

This article offers an analysis of the Latin translation of Galen's De antidotis made by the physician and humanist Josephus Struthius. He did not, as he claimed, resort to an ancient manuscript containing De antidotis for his translation, and his criticisms against the Latin translation of De antidotis made by the physician and humanist Joannes Guinterius is in many ways unjustified. Struthius, it seems, adopted a self-representation strategy that resembled that adopted by Galen.

Cet article propose une étude préliminaire de la traduction latine du De antidotis de Galien faite par le médecin et humaniste Josephus Struthius. Il n'a apparemment pas recouru à l'ancien manuscrit contenant De antidotis qu'il dit avoir employé pour sa traduction; sa critique contre la traduction latine du De antidotis faite par le médecin et humaniste Joannes Guinterius est au moins partiellement injustifiée. Struthius adopte une stratégie d'auto-représentation qui rappelle celle de Galen.

INDEX

Keywords: Struthius, Guinterius, De antidotis, manuscripts, translation, Galen

Mots-clés: Struthius, Guinterius, De antidotis, manuscrits, traduction

\section{AUTHOR}

\section{SIMONE MUCCI}

University of Warwick 